\title{
O początkach kościoła i parafii w Tuligłowach Przyczynek do historii struktur Kościoła łacińskiego w diecezji przemyskiej
}

Zarys treści: Początki i rozwój organizacji Kościoła katolickiego na Rusi są słabo rozpoznane, a wymagają studiów nad poszczególnymi parafiami. Artykuł dotyczy kościoła we wsi Tuligłowy, uważanego za jeden najstarszych w diecezji przemyskiej. Powstał on faktycznie w drugiej połowie XV w., prawie sto lat później niż dotąd sądzono. Następnie przejęli go, korzystając ze sfałszowanych dokumentów, bożogrobcy z Miechowa.

Content outline: The beginnings and development of the organisation of the Catholic Church in Rus' have not been satisfactorily researched and require detailed studies on individual parishes. The paper deals with the church in the village of Tuligłowy, regarded as one of the oldest churches in the diocese of Przemyśl. Actually, it was founded in the second half of the $15^{\text {th }}$ century, almost a hundred years later than believed so far. Then the Order of the Holy Sepulchre from Miechów took it over, using fake documents.

Słowa kluczowe: Kościół na Rusi, parafie, bożogrobcy, Miechów, Tuligłowy, Rudołowice

Keywords: Church in Rus', parishes, Order of the Holy Sepulchre, Miechów, Tuligłowy, Rudołowice

Problem początków i rozwoju organizacji Kościoła katolickiego w diecezji przemyskiej od dawna zajmował badaczy ${ }^{1}$. Mimo stosunkowo bogatej literatury odnoszącej się do szeroko pojętych dziejów tej diecezji, stan wiedzy o rozwoju sieci parafialnej, a zwłaszcza o poszczególnych kościołach, jest ciągle niezadowalający. $\mathrm{Na} 163$ parafii na tym obszarze jedynie kilkanaście posiada w miarę wyczerpujące opracowania $^{2}$. Dla zdecydowanej większości nie znamy dokumentów fundacyjnych i erekcyjnych. Nieliczne zaś zachowane do naszych czasów bywają sfałszowane lub podfałszowane w czasach późniejszych, co powoduje błędne datowanie powstania wielu placówek, a w efekcie nieprecyzyjny obraz rozwoju sieci parafialnej. Konsekwencją takiego stanu rzeczy jest podniesiony ostatnio przez Grzegorza Klebowicza brak wyczerpującej syntezy dziejów Kościoła przemyskiego, spełniającej wymogi stawiane współcześnie tego typu opracowaniom³ ${ }^{3}$. Aktualny pozostaje zatem postulat

1 Stan badań przedstawił ostatnio wyczerpująco G. K 1 e b o w i c z, Organizacja parafialna diecezji przemyskiej obrządku łacińskiego w XIV-XVI wieku, Lublin 2013, s. 15-45.

2 Tamże, s. 27-31.

3 Tamże, s. 15-16. 
dogłębnych badań nad historią poszczególnych kościołów w kontekście stosunków osadniczych, własnościowych i prawnych, a także krytyki zachowanych źródeł dyplomatycznych. Dopiero suma szczegółowych ustaleń dać może solidne podstawy do wypracowania ogólnego obrazu poszczególnych fundacji.

Znakomitym przykładem zasygnalizowanych problemów są początki kościoła i parafii w Tuligłowach oraz okoliczności przejęcia ich przez bożogrobców. Kościół ten utracił swoje dokumenty już na przełomie XV i XVI w. w dość niejasnych okolicznościach, o których będzie jeszcze mowa, a za fundacyjny uchodzi wielokrotnie oblatowany później fałszywy dokument biskupa przemyskiego Macieja, pochodzący rzekomo z 1396 r. i potwierdzający uposażenie kościoła rudołowickiego (Aneks nr 3). Ponieważ kościół tuligłowski powstał na terenie parafii rudołowickiej, do wyjaśnienia jego początków konieczne jest przeanalizowanie przekazów odnoszących się do Rudołowic, wyją̧tkowo posiadających dokumenty fundacji z 1393 i uposażenia z 1394 r. (Aneks nr 1-2), a także szereg późniejszych oryginałów i kopii istotnych dla niniejszych rozważań (Aneks nr 4, 5, 6). Początki kościoła rudołowickiego są więc dobrze udokumentowane, a wątpliwości budzą jedynie okoliczności i prawne aspekty przejęcia go przez bożogrobców, natomiast czas powstania świątyni w Tuligłowach, wyodrębnienia się własnej parafii, wreszcie ustalenie uprawnień patronackich nie zostały dotąd należycie wyjaśnione.

Wedle miejscowej, późnej i bałamutnej tradycji, spisanej podczas wizytacji w 1744 r. $^{4}$, w miejscu, gdzie stał później (w XVI w.) zbór luterański, dziedzic Tuligłów - nieznany skądinąd Adam Mzurowski - w podzięce za przywrócone za wstawiennictwem NMP życie synowi wystawił w końcu XIV w. kaplicę dla cudownego obrazu Matki Bożej (który w rzeczywistości przywieziony tam został dopiero w XVII w. z zamku w Kudryńcach na Podolu ${ }^{5}$ przez uchodzącego przed

${ }^{4}$ Archiwum Archidiecezji Przemyskiej (dalej cyt.: AAP) 166, k. 143-143v, 145: In hac villa ubi antea fanum lutheranum extiterat aedificatum, capella pro locanda miraculosa Beatissimae Virginis Mariae immaculatae conceptae imagine - - in recognitionem beneficiorum insignium, et praecipue quod infans, filius mortuus m. Adami Mzurowski villae Tuligłowy haeredis per intercessionem Beatissimae vitae restitutus fuerat, per eundem M. Adamum Mzurowski capella praedicta aedificata extiterat et postea ecclesiae parochiali Rudoloviensi affiliata. Magnificus Nicolaus Mzurowski m. Adami capellae fundatoris germanus frater legittimus, bonorum Rudołowice, Tuligłowy, Rudniki, Bystrowice, Więckowice, Czastkowice, Strzelczyce, Wegierka, et eiusdem villae Wola Wegierska haeres, ecclesiae in villa hac Tuligłowy primum initium dedit et illustrissimus Mathias episcopus Praemisliensis eandem per eundem magnificum dotatam in parochialem anno 1396 erexit, approbavit et confirmavit. Inną w szczegółach wersję historii obrazu zanotował w 1728 r. ówczesny pleban tuligłowski Walerian Skalski (Biblioteka Książąt Czartoryskich w Krakowie, rkp. 2892, s. 413-414).

5 Słynący cudami obraz Matki Bożej pojawił się w Tuligłowach zapewne około połowy XVII w. O obrazie nie wspomina jeszcze Samuel Nakielski, Miechovia sive promptuarium antiquitatum monasterii Miechoviensis, Cracoviae 1634-1646, ani wizytacja biskupa Pawła Piaseckiego z 1646 r., natomiast 8 IV 1663 r. ówczesny dziedzic Tuligłów Adam Władysław Krasicki, powiększając uposażenie kościoła, zalecił w zamian odprawianie w każdą sobotę przed ołtarzem Matki Bożej mszy św. wotywnej z litanią do NMP, co wskazuje na powstający już kult (AAP 1778, k. 29). W 1653 r. miał w Kudryńcach (parafia Czarnokozińce) stać koszem chan tatarski (Słownik geograficzny Królestwa Polskiego i innych krajów słowiańskich, t. IV, Warszawa 1883, s. 846). 
„bisurmanami”, zapewne Turkami, tamtejszego kapelana). Kaplica ta miała zostać podporządkowana parafii w Rudołowicach. Brat zaś owego Adama, Mikołaj Mzurowski, ufundował następnie w Tuligłowach kościół, przy którym w 1396 r. biskup Maciej erygował odrębną parafię.

W ślad za tym przekazem cała dotychczasowa historiografia kładzie początki kościoła w Tuligłowach na lata dziewięćdziesiąte XIV w. Część autorów wskazuje jako datę jego powstania 1393, część zaś 1396 r. ${ }^{6}$ Wznieść go miał ówczesny dziedzic Rudołowic i Tuligłów Mikołaj Mzurowski herbu Amadej ${ }^{7}$. Równie zgodnie przyjmuje się, że kościół tuligłowski był początkowo filią kościoła parafialnego w Rudołowicach. Dopiero niedawno Ryszard Skrzyniarz zauważył, iż „w historiografii utarło się, że parafia w Tuligłowach była filią kościoła w Rudołowicach, jednak źródła wskazują, że była niezależną placówką parafialną"». Ten skądinąd słuszny wniosek autor wyciągnął jednak na podstawie źródeł odnoszących się do kościoła parafialnego w innych Tuligłowach, w archidiecezji lwowskiej ${ }^{9}$. Jakie były zatem rzeczywiste początki kościoła i parafii w Tuligłowach?

Dnia 21 X 1393 r. Mikołaj Mzurowski wystawił dokument uposażeniowy dla wzniesionego przez siebie kościoła w Rudołowicach pod wezwaniem św. Mikołaja (Aneks nr 1). Na uposażenie składały się typowe w tym czasie składniki: dziesięcina z ról dworskich w Rudołowicach, 11/2 łanu roli, osobna łąka, karczma i sadzawka

${ }^{6}$ Informacja o fundacji kościoła tuligłowskiego w 1393 r. pojawiła się po raz pierwszy w schematyzmie diecezji przemyskiej: A.D. 1393 per Nicolaum Mzurowski haeredem in Tuligłowy, Rudołowice, Więckowice, Rudniki, Strzelczyce, hic loci capella fundata fuit, quae serius in ecclesiam parochialem mutata est (Schematismus universi venerabilis cleri saecularis et regularis dioeceseos ritus latini Premisliensis pro anno 1867, Jasło 1866, s. 46). Powtórzył ją autor hasła w Słowniku geograficznym, t. XII, s. 615: „W 1393 Mikołaj Mzurowski dziedzic wsi [Tuligłowy] zbudował tu kaplicę, którą później zamieniono na kościół parafialny". Pośrednio, poprzez osobę fundatora, tak samo datuje powstanie kościoła M. To b i a s z, Bożogrobcy w Miechowie (w 800-lecie sprowadzenia zakonu do Polski), Nasza Przeszłość 17, 1963, s. 56: „Rudołowice - Tuligłowy posiadały kościoły wybudowane przez dziedzica Mikołaja Mzurowskiego". Na 1393 r. datuje powstanie kaplicy w Tuligłowach J. Kuś, Jeszcze o manach jarosławskich. Szkic historyczno-archiwalny, w: Księga pamiątkowa [poświęcona doktorowi Zdzisławowi Koniecznemu z okazji 70. rocznicy urodzin], Przemyśl 2000, s. 111. Ostatnio na temat początków kościoła tuligłowskiego wypowiedzieli się G. K l e b o w i c z, Organizacja, s. 290-292, 320-321, 471 (datując go na lata 1393-1396), oraz R. S k r z y n i a r z, Kanonicy Grobu Bożego i ich religijny, społeczny, edukacyjny i kulturowy wkład w rozwój mieszkańców ziem polskich w średniowieczu, Lublin 2015, s. 124, 407 (który całkowicie błędnie, na podstawie dokumentu uposażeniowego kościoła w Rudołowicach z 1393 r., uznał, że wówczas też nastąpiła fundacja i uposażenie kościoła w Tuligłowach). Na 1396 r. kładł powstanie parafii tuligłowskiej F. P a wł o w s k i, Premislia sacra, Kraków 1869, s. 82.

7 J. K u ś, Jeszcze o manach, s. 111, a za nim G. Kle b ow i c z, Organizacja, s. 290, niesłusznie przydają im herb Nieczuja. Przynależność do rodu Amadejów potwierdza pieczęć jego syna Jana przywieszona do aktu szlachty przemyskiej potwierdzającej prawo Władysława Jagiellończyka do tronu z 1433/34? r. (F. P i e k o s i ń s k i, Jana Zamoyskiego notaty heraldyczno-sfragistyczne, w: tegoż, Studia, rozprawy i materyały z dziedziny historii polskiej i prawa polskiego, t. VII, Kraków 1907, nr 340). Tak samo S. Nakielski, Miechovia, s. 480. Tak też podaje S. K u r a ś (Zbiór dokumentów małopolskich, t. I-VIII, wyd. S. Kuraś, I. Sułkowska-Kurasiowa, Wrocław 1962-1975 [dalej cyt.: ZDM], tu t. IV, nr 1102, przyp. 10).

${ }^{8}$ R. S k r z y n i a r z, Kanonicy, s. 125.

9 Tamże, s. 125, 300-301. 
w tej wsi oraz meszne i inne daniny od mieszkańców Rudołowic, Więckowic, Bystrowic i Tuligłów, a więc z wszystkich dóbr, jakie wówczas posiadał fundator w tej części ziemi przemyskiej i które weszły w skład nowej parafii ${ }^{10}$. Dokument ten, zachowany do naszych czasów, jest autentyczny, o czym przekonują zarówno znamiona zewnętrzne, jak i wewnętrzne: język, formularz, dyktat, elementy prawne i historyczne, w tym świadkujące osoby. Został on jednak w dwóch miejscach interpolowany, jak wskazuje razura z dopiskiem wniesionym inną ręką (naśladującą pismo oryginału) oraz porównanie z kopiami zawierającymi prawidłową treść. W miejsce słów: sex stadiorum ex opposito templi, wprowadzono znamienne, anachroniczne sformułowanie: sex stadios pro prepos it o templi. Interpolacja ta została dokonana po 1536, kiedy oryginał jeszcze bez wspomnianej zmiany został wpisany do ksiąg oficjalatu przemyskiego, a przed 1634 r., kiedy Nakielski w swym wydaniu wydrukował już: sex stadiorum praeposito templi ${ }^{11}$. Miejsce to, znajdujące się na zgięciu karty, musiało być jednak już w 1536 r. słabo czytelne, skoro pisarz oficjalatu zinterpretował ten fragment jako: scilicet medium ex opposito templi ${ }^{12}$. Po 1536 r. zmieniono także inny fragment: in area, na: cum area. Powyższe interpolacje dotyczą jednak tylko uposażenia kościoła w Rudołowicach i nie zmieniają faktu, że Tuligłowy zostały włączone do nowo powstałej parafii rudołowickiej.

Pół roku później, 28 IV 1394 r., w Przemyślu biskup Maciej, mając na względzie szczupłość dotychczasowego uposażenia, dodał do niego za zgodą kapituły katedralnej dziesięciny z ról kmiecych w Rudołowicach i Tuligłowach (Aneks nr 2). Także ten dokument zachowany jest w oryginale i nie budzi wątpliwości co do autentyczności. W obu wspomnianych dokumentach brak jeszcze jakiejkolwiek informacji o istnieniu świątyni w Tuligłowach, czy też choćby sugestii zamiaru jej wzniesienia ${ }^{13}$.

Trzeci z dokumentów, błędnie, jak wspomnieliśmy, określany jako akt fundacyjny kościoła w Tuligłowach, nosi datę 1396 i miał być wystawiony przez biskupa przemyskiego Macieja (Aneks nr 3). Jest to jednak ewidentny falsyfikat powstały najpewniej pod koniec XV w. Do tego czasu zdaje się przynależeć pismo, najważniejsze są jednak znamiona wewnętrzne. Dokument ma bardzo ułomny formularz. Brak inwokacji, wystawca przedstawia się w nietypowej, obiektywnej formie (Nobis Mathie, Dei gracia episcopo Premisliensi), nieznanej z innych dokumentów tego biskupa ${ }^{14}$. Brak

10 Aneks nr 1. Niesłusznie G. K 1 e b o w i c z, Organizacja, s. 290-291, dopatruje się w tym nadaniu dziesięciny kmiecej i jakichś szczególnych okoliczności tego nadania. W dokumencie zapisano wprawdzie de tota aratri cultura, ale chodzi wyłącznie o całość ról dworskich. Do nadania dziesięcin z ról kmiecych fundator nie miał uprawnień, o czym zresztą świadczy dokument z wiosny następnego roku, którym biskup Maciej za zgodą kapituły przekazał te właśnie dziesięciny nowo erygowanemu kościołowi. Podobnie R. S k r z y n i a r z, Kanonicy, s. 407, który dodatkowo podaje błędną nazwę wsi Więckowice jako „Woczkowice”.

11 S. Nakielski, Miechovia, s. 345.

12 W dekrecie wizytacyjnym z 1699 r. zanotowano, że pleban rudołowicki posiada unum integrum mansum ex opposito templi iuxta piscinam et medium respicientem Jaroslaviam (AAP 155, k. 114).

13 R. S k r z y n i a r z, Kanonicy, s. 408, błędnie pisze, że dokumentem tym biskup Maciej te dziesięciny nadał „kościołowi w Rudołowicach i filii kościoła w Tuligłowach”.

14 AGZ VIII, nr 22, 23, 27, 30, 31, 34, 40; ZDM IV, nr 1111, 1113, 1132, V, nr 1162, 1275, VI, nr 1864. 
w nim arengi, promulgacji i sankcji. Datacja pozbawiona jest miejsca wystawienia i daty dziennej. Tekst jest niejasny, zawikłany. Nie przekonuje wyrażona w nim intencja potwierdzenia wcześniejszego zaledwie o trzy lata nadania fundatora, co wobec wystawienia przez tegoż biskupa dokumentu potwierdzającego i rozszerzającego nadanie (1394) nie miało żadnego uzasadnienia. Rzeczywistym powodem sporządzenia owego falsyfikatu było ekstrapolowanie sytuacji z drugiej połowy XV w., tj. istnienia kościoła w Tuligłowach, do warunków o sto lat wcześniejszych oraz rozszerzenie pierwotnego nadania fundatora o świadczenia z ról dworów powstałych $\mathrm{w}$ drugiej połowie XV w. (Bystrowice i Tuligłowy), a także z dwóch wsi niewymienionych w dokumencie z 1393 r., tj. Węgierki i nowo lokowanej Woli. Fałszerstwo zdradza zwłaszcza wzmianka o tej ostatniej wsi, gdyż powstała ona dopiero w drugiej połowie $\mathrm{XV} \mathrm{w.}{ }^{15}$ Od strony językowej anachroniczne wydaje się użycie słowa condecernens, nieznanego z żadnego innego polskiego tekstu średniowiecznego ${ }^{16}$. Rażą też sztucznie archaizowane nazwy miejscowości (Byszthrzyowycze, Wnczkowicze, Vynczkowicze), w tym trzy różne wersje tej samej nazwy (Tvlyglowy, Twlyghlowy, Tuliglowy) oraz anachroniczne predykaty (generosus et nobilis czy honorabili et idoneo). Wątpliwości budzi wymienienie świadków w środku tekstu i ich skład, który (poza jednym Stachnikiem z Czelatyc) pokrywa się z testacją dokumentu z 1393 r. Ta sama lista świadków (jedynie bez Ptaczka z Jankowic i Stachnika z Czelatyc) została zresztą użyta także w innym falsyfikacie sporządzonym pod imieniem biskupa Macieja z datą 9 I 1420 r., a dotyczącym zatwierdzenia fundacji kościoła w Urzejowicach, który również przejęty został przez bożogrobców ${ }^{17}$.

Kolejne dwa dokumenty (Aneks nr 4 i 6) znane są tylko z Miechovii Samuela Nakielskiego i nigdy nie były oblatowane. Nie jest zatem możliwa ich autopsja ani też porównanie kopii. Fakt nieoblatowania jest zaskakujący zwłaszcza w stosunku do pierwszego z dokumentów (z datą 1446 r.), mocą którego konwent miechowski miał otrzymać kościoły w Rudołowicach i Tuligłowach; dyplom ten stanowił wszak podstawę uprawnień bożogrobców wobec obu kościołów. Analiza tego przekazu wskazuje, że jest on sfałszowany, choć może zawierać elementy faktycznej decyzji rzekomych wystawców. Razi rozwlekłość dyktatu, skład świadków (sami duchowni i bliżej nieznany szlachcic Jan de Turkowice), a zwłaszcza kontekst historyczny i prawny. Dokument wystawiony został w Przeworsku 2 V 1446 r. przez braci Jana z Mzurowa stolnika przemyskiego i Mikołaja oraz ich (eorum) synów Jana i Mikołaja dziedziców Rudołowic. Już ten fragment budzi wątpliwości, gdyż Mikołaj był od 1437 r. miecznikiem przemyskim, natomiast nie był dziedzicem Rudołowic, które w całości przypadły jego bratu stolnikowi. Obaj mieli synów o tym samych imionach, Jana i Mikołaja. O czyich zatem synów w dokumencie chodzi? Omawianym dokumentem mieli oni darować wieczyście bożogrobcom kościoły parafialne w Rudołowicach i Tuligłowach wraz z prawem prezenty (ius praesentandi). Uprzedzając dalszy wywód, podnieść trzeba, że parafialny status kościoła tuligłowskiego po raz pierwszy potwierdzony jest skądinąd dopiero w 1471 r. Rozważany dokument

15 M. Wolski, Dzieje Pruchnika i okolic do końca XVI wieku, w: Pruchnik. Studia z dziejów miasta i okolic, Kraków 2014, s. 52, 56-57, 62.

16 Słownik łaciny średniowiecznej w Polsce, t. II, Wrocław 1959-1967, kol. 870-871.

17 ZDM V, nr 1316. 
interpretowany był dotychczas jako bezwarunkowe ustąpienie patronatu na rzecz konwentu miechowskiego ${ }^{18}$. Należy go jednak rozumieć nieco inaczej. W dalszej części tekstu znalazły się bowiem znamienne warunki: Ita tamen, quod nos et successores nostri legitimi fratres de monasterio praedicto Miechoviensi debebimus extunc [w tym miejscu winno być orzeczenie np. ducere, analogicznie do dalszej części dokumentu: duxerimus] in rectores bonos et valentes etiam exemplares, quos ipsi dominus praepositus cum suis fratribus tenebuntur ad investiendum canonice et confirmandum loci ordinario temporibus perpetuis mittere et praesentare, oraz: In casu, si praedicti fratres per ipsos praepositum et fratres de Miechow ad praedictas ecclesias gerendas missi et praesentati et per loci ordinarium confirmati boni et valentes non extiterint, extunc ipse dominus praepositus una cum fratribus suis et successores, fratres ex causis rationabilibus ad monasterium ipsorum revocare debent, et ecclesiis praefatis villarum nostrarum alios fratres loco ipsorum, quos nos duxerimus cum successoribus nostris legitimis ad regendum easdem ecclesias, et per ordinarium investiendum praesentare debent. Z przytoczonych fragmentów wynika, że Mzurowskim pozostawiono prawo wyboru kandydata spośród braci zakonnych oraz możliwość interwencji w przypadku złego zarządzania parafią ${ }^{19}$.

W odniesieniu do kościoła w Tuligłowach przekazaniu go bożogrobcom przeczy kilka faktów. Po pierwsze, Tuligłowy były własnością królewską, a zatem ewentualna fundacja kościoła w tej wsi i następnie przekazanie praw patronackich do niej, musiałyby się odbyć za zgodą monarchy. Ponadto Mzurowscy utracili Tuligłowy pomiędzy 1437 a 1442 r. ${ }^{20}$ Nie jest zatem możliwe, aby w 1446 r. i później mogli scedować na konwent miechowski jakiekolwiek prawa do tamtejszego kościoła.

Kwestią otwartą pozostaje natomiast faktyczna data sporządzenia owego falsyfikatu. Skład wystawców odpowiada sytuacji z końca 1453 i początku 1454 r., kiedy Jan z Mzurowa był wojskim (po raz pierwszy notowany 8 XI 1453 r.), a nie

18 P. P ę k a ls k i, O początku, rozkrzewieniu i upadku zakonu XX. Kanoników Stróżów św. Grobu Pańskiego, Kraków 1867, s. 75-76; M. To b i a s z, Bożogrobcy, s. 56; Z. P ę c k o w s ki, Miechów. Studia z dziejów miasta i ziemi miechowskiej do roku 1914, Kraków 1967, s. 351; T. M. Tr a j d o s, Miechowici na ziemi przemyskiej za panowania Władysława II Jagiełły, Folia Historica Cracoviensia 4-5, 1997-1998, s. 97; R. S k r z y n i a r z, Źródła archiwalne w Polsce do dziejów zakonu Bożogrobców, w: Bożogrobcy w Polsce. Praca zbiorowa, Miechów-Warszawa 1999, s. 218; W. B u k o w s k i, Miechów, w: Słownik historyczno-geograficzny województwa krakowskiego w średniowieczu, cz. IV, Kraków 2009, s. 394; G. K l e b ow i c z, Organizacja, s. 292, 320-321; R. S k r z y n i ar z, Kanonicy, s. 124, 161 (tu błędny odsyłacz do dokumentu: Warszawa, Archiwum Główne Akt Dawnych [dalej cyt.: AGAD] dok. perg. 2564).

19 W późniejszych źródłach nie znajdujemy jednak śladu udziału Mzurowskich w wyłanianiu kandydatów na wakujące beneficium rudołowickie, a w prezencie na nie z $1536 \mathrm{r}$. zapisano wręcz, że kandydat został wybrany przez bożogrobców canonice et capitulariter (AGAD dok. perg. 2717).

${ }^{20}$ W dniu 25 XI 1437 r. na wiecu w Przemyślu podkomorzy Jan Derszniak wyznaczył na 12 II 1438 r. termin rozgraniczenia Tuligłów należących do Jana z Mzurowa od Woli Rokietnickiej tegoż Derszniaka, Tuliczowa Piotra z Próchnika i Chorzowa Jaczka z Rozborza (AGZ XIII, nr 7323). Przed 10 III 1442 r. Tuligłowy znalazły się w rękach Jana Żmigrodzkiego (AGZ XI, nr 1444; A. F a s t $\mathrm{n}$ a c h t, Słownik historyczno-geograficzny ziemi sanockiej w średniowieczu, cz. 3, Kraków 2002, s. 91). 
stolnikiem przemyskim, jak jego ojciec, jego brat zaś Mikołaj nie piastował jeszcze urzędu miecznika (po raz pierwszy z urzędem tym występuje 11 IV 1454 r.) $)^{21}$. Ponadto Mikołaj był jeszcze wówczas najpewniej kawalerem, natomiast Jan miał już dwóch synów: Jana (urodzonego ok. 1440) i młodszego Mikołaja 22 . W tym czasie bracia nie podzielili jeszcze między sobą majątku ojczystego, a zatem byli współwłaścicielami Rudołowic. Podział nastąpił zapewne przed 9 V 1454 r., kiedy Mikołaj pisał się już z Kidałowic, a Jan - z Bystrowic ${ }^{23}$. Istotny dla kwestii datacji owego falsyfikatu jest też kolejny dokument, również znany tylko z kopii (Aneks nr 6); miał on być wystawiony przez synów stolnika Jana Mzurowskiego: Jana wojskiego i Mikołaja miecznika przemyskich w Rudołowicach 2 X 1454 r. Dotyczył nadania kościołowi w Rudołowicach dwóch łąk (jednej w Bystrowicach, drugiej zaś w Rudołowicach) jako zadośćuczynienia za jakieś krzywdy wyrządzone przez nich po śmierci poprzedniego plebana Aleksego. Zarówno urzędy sprawowane przez wystawców, jak i świadkowie odpowiadają podanej w dokumencie dacie. Znamienne jest natomiast to, że obaj bracia wystąpili jako kolatorzy kościoła w Rudołowicach, a więc osiem lat po rzekomej donacji z 1446 r. Dokument ten był zapewne autentyczny, acz został dość nieudolnie interpolowany przez nachalne i w niektórych miejscach nielogiczne i niegramatyczne wprowadzenie odwołań do związków z konwentem miechowskim, np.: Ioannes tribunus et Nicolaus gladifer Praemislienses, fratres germani, haeredes vero veri et legitimi perpetuique villarum in Rudolowice et Bystrowice, collatores vero in Rudolowice, ordinis Sacrosancti Sepulchri Domini Hierosolymitani, czy: Nicolao plebano de Rudolowice eiusdem ordinis. Zwraca też uwagę fakt, że wśród świadków brak przedstawiciela przeworskiego konwentu bożogrobców, którego obecność byłaby w pełni uzasadniona. Warto też zauważyć, że w 1448 r., gdy Jan Gołuchowski z Roźwienicy uposażył kościół w Rudołowicach dziesięciną z folwarku w tej wsi oraz mesznym z Roźwienicy i Woli Roźwienickiej, odbiorcą był pleban Mikołaj, zapewne tożsamy z wzmiankowanym w 1454 r., a w tekście ani razu nie pojawiło się odniesienie do konwentu bożogrobców (Aneks nr 5). Zaznaczono jedynie, że nadanie służyć ma w przyszłości następnym plebanom, niezależnie od tego, czy będą to zakonnicy czy księża świeccy (sive sit regularis, sive irregularis). Ponadto Gołuchowski zażądał, aby w kościele został przez plebana i kolatorów wzniesiony specjalny ołtarz dla odprawiania mszy. Nie wspomniał nic o bożogrobcach, których także i tu nie znajdujemy w testacji, ale pojawiają się za to Mikołaj i Jan dziedzice Rudołowic, synowie stolnika przemyskiego Jana Mzurowskiego ${ }^{24}$.

Powracając do kwestii datacji falsyfikatu z 1446 r., należy więc przyjąć, że w rzeczywistości Mzurowscy sprawowali patronat nad kościołem w Rudołowicach co najmniej do 1454 r. Hipoteza taka zgadzałaby się ze stwierdzeniem S. Nakielskiego, który zapisał, że konwent wszedł w posiadanie kościołów, a właściwie

21 AGZ XIII, nr CCCXXVIII; nr 4384.

${ }^{22}$ W 1485 r. Jan osobiście zeznał, że ma ok. 45 lat (AAP 9, k. 154v).

23 AGZ XIII, nr 4385.

${ }^{24}$ S. Kuraś błednie identyfikuje świadkującego tu Mikołaja jako Mikołaja Gronostaja, syna Piotra, który nabył Rudołowice w 1456 roku od Mikołaja Mzurowskiego syna stolnika Jana (ZDM III, nr 790, przyp. 10). 
kościoła, ok. 1453 r.: Duae posthaec ecclesiae parochiales Rudolouiensis nempe et Tuliglouiensis - - ordini nostro accesserunt quinquagesimo fere tertio anno ${ }^{25}$. Nakielski jednak w innym miejscu, zaprzeczając samemu sobie, podaje, że Mikołaj, jakoby drugi z kolei pleban miechowita, zmarły w 1468 r., pełnił swą funkcję przez 14 lat, czyli od ok. $1454 \mathrm{r}^{26}$ Ponieważ te sprzeczne informacje nie zasługują na wiarę, jast wielce prawdopodobne, że konwent wszedł w posiadanie kościoła rudołowickiego dopiero po śmierci plebana Mikołaja - co uzasadniałoby użycie $\mathrm{w}$ dokumencie z $1448 \mathrm{r}$. (Aneks $\mathrm{nr}$ 5) warunkowego trybu (sive sit regularis sive irregularis) - a zatem wówczas pierwszym plebanem z ramienia bożogrobców byłby znany ze źródeł właśnie od 1468 r. Piotr, ewidentny miechowita ${ }^{27}$.

Patronat nad kościołem rudołowickim, tak jak w przypadku innych fundowanych w podobnym czasie w sąsiedztwie kościołów (Pruchnik, Pantalowice, Rokietnica), związany był niewątpliwie z własnością danej $\mathrm{wsi}^{28}$. Rudołowice wyszły z rąk tej linii Mzurowskich w 1456 r., ale w dokumencie zamiany nie wspomniano o przekazaniu nabywcom praw patronackich ${ }^{29}$. Przypuszczać zatem można, że stało się tak dlatego, iż stolnik przemyski Jan Mzurowski przed swoją śmiercią (zm. 1446/1447) poczynił obietnicę przekazania miechowitom patronatu nad kościołem rudołowickim po śmierci dotychczasowego plebana Mikołaja, a więc w 1456 r. patronat nie wchodził już do masy majątkowej Mzurowskich. Wydaje się prawdopodobne, że rozważany falsyfikat mógł zatem oddawać rzeczywistą wolę stolnika Jana, zmarłego zaledwie pół roku po dacie, jaką opatrzono dokument, oraz jego brata Mikołaja, zmarłego około pięciu lat później3 ${ }^{30}$. Podobnie postąpili miechowici, fabrykując wkrótce po śmierci Spytka Jarosławskiego dokument w sprawie Świętoniowej Woli, gdy „wspomnienia [były] świeże, ale rzekomy wystawca darowizny odszedł już z tego świata. Tym samym wykładnia jego hojności należała do miechowitów, a gest zaufania - do jego synów”31. W naszym przypadku owa „wykładnia hojności” odnosiła się do kościoła tuligłowskiego, nieistniejącego jeszcze za życia darczyńców. Antedatowanie zaś akcji prawnej do 1446 r. miało zabezpieczyć bożogrobców przed zdemaskowaniem fałszerstwa przez wnuków wystawców. Zabieg ten spowodował jednak, że dwaj kolejni plebani Aleksy (zm. przed 1448) i Mikołaj (zm. 1468) musieli zostać przez Nakielskiego, świadomego fałszerstwa czy też nie, uznani za miechowitów. Sfabrykowanie natomiast samego dokumentu nastąpiło znacznie później, być może

25 S. Nakielski, Miechovia, s. 480.

26 Tamże, s. 527: infra quod tempus Nicolaus Rudolouiensis plebanus quattuor decimo [1454] regiminis sui anno mortem opeciit [!], cui e vestigio vocis communibus fratrum quidam frater Ioannes ordine tercius surrogatus est. Następstwo Jana po Mikołaju nie znajduje potwierdzenia w materiale źródłowym.

${ }^{27}$ W 1471 r., nie mogąc osobiście wziąć udziału w kapitule generalnej w Miechowie, wyznaczył swego zastępcę (W. B u k o w s k i, Miechów - klasztor, w: Słownik historyczno-geograficzny województwa krakowskiego w średniowieczu, cz. IV, s. 394).

${ }^{28}$ B. S z a d y, Prawo patronatu w Rzeczypospolitej w czasach nowożytnych. Podstawy i struktura, Lublin 2003, s. 31.

29 AGAD, Metryka Koronna, t. 11, s. 57-58; regest: MRPS I, nr 2611.

30 Stolnik przemyski Jan Mzurowski zmarł między 1 XII 1446 a 2 III 1447 r. (AGZ XIII, nr 3057, 3468), a miecznik Mikołaj - po 26 III 1451 r. (AGZ XIII, nr 4306).

31 ZDM II, nr 404; T. M. Tra j d o s, Miechowici na ziemi przemyskiej, s. 85-88. 
na początku lat osiemdziesiątych XV w., razem z drugim (datowanym na 1396 r.) i miało posłużyć przejęciu parafii tuligłowskiej.

Przechodząc obecnie do zasadniczej kwestii, to jest czasu i okoliczności powstania kościoła w Tuligłowach, powtórzyć należy, że tamtejszy kościół nie mógł powstać w 1393 ani też w 1394 r., gdyż nadanie dziesięcin kmiecych oraz mesznego z tej wsi odbierałoby podstawy egzystencji miejscowemu plebanowi. Fundacja nie nastąpiła też przed 1396 r., gdyż - jak to pokazaliśmy - dokument noszący tę datę jest falsyfikatem z drugiej połowy XV w. Nie jest miarodajny także rok 1446, gdyż datowany tak falsyfikat pochodzi najpewniej także z lat osiemdziesiątych XV w.

W 1450 r. Kazimierz Jagiellończyk nadał wieczyście (perpetue et in aevum) Tuligłowy wraz z grodziskiem (zwanym obecnie Borusz) ${ }^{32}$ i lasem ciągnącym się w stronę Maćkowic kanclerzowi koronnemu Janowi Taszce z Koniecpola ${ }^{33}$. Wśród składników majątkowych w Tuligłowach dokument nie wymienia kościoła, nie przekazuje też ani nie rezerwuje prawa patronatu nad jakąkolwiek świątynią. Zdaje się to przesądzać, że wówczas w Tuligłowach nie było jeszcze żadnego kościoła. W następnych latach Tuligłowy nie miały charakteru rezydencjonalnego, a kanclerz i starosta sieradzki Jan z Koniecpola mieszkał w nieco oddalonej Rączynie, posiadając tam znane z zapisu z 1468 r. fortalicium ${ }^{34}$. Wątpliwe więc, aby powziął zamysł wzniesienia w Tuligłowach osobnego kościoła.

Po śmierci kanclerza (zm. 26 III 1455) Tuligłowy wraz z pozostałymi dobrami spadły na jego synów Jana, Jakuba i Przedbora ${ }^{35}$. W 1462 r. bracia dokonali podziału dóbr, w którym te leżące w ziemi przemyskiej przypadły najstarszemu Janowi ${ }^{36}$. Między 1465 a 1466 r. doszło jednak do zamiany działów braterskich i dobra przemyskie wziął ksiądz Jakub Koniecpolski prepozyt św. Floriana w Krakowie ${ }^{37}$. Ten zaś, niezainteresowany gospodarowaniem w oddalonych od głównych centrów aktywności życiowej wsiach, sprzedał w 1467 r. Tuligłowy chorążemu przemyskiemu i późniejszemu sędziemu ziemskiemu Janowi Dolińskiemu z Bylic za 300 grzywien, zastrzegając jedynie prawo odkupu w ciągu 4 lat dla siebie i swoich braci Jana lub Przedbora ${ }^{38}$.

Choć można by podejrzewać księdza Jakuba o inicjatywę wzniesienia w Tuligłowach kościoła, to z uwagi na wspomniany brak zaangażowania w gospodarowanie

32 A. W ę d z k i, Tuligłowy, w: Słownik starożytności słowiańskich, t. VI, Wrocław 1977, s. 201; M. Proks a, Studia nad zamkami i dworami ziemi przemyskiej, Przemyśl 2001, s. 390 (tu starsza literatura).

33 ZDM III, nr 852; A. S z y m c z a k o w a, Szlachta sieradzka do końca XV wieku. Magnifici et generosi, Łódź 1998, s. 41; W. Z a w i t k o w s k a, W służbie pierwszych Jagiellonów. Życie i działalność kanclerza Jana Taszki Koniecpolskiego, Kraków 2005, s. 230, 320, 340; AGZ XIII, nr 905, 2635. Kanclerz już wcześniej posiadał w tej okolicy inne królewszczyzny, Rączynę i Zagórze, nadane mu w 1433 r. (ZDM VII, nr 2147; W. Z a w it k o w s ka, W służbie, s. 140, 320, 337).

${ }^{34}$ AGZ XIII, nr 6849, 7087; W. Z a w it k o w s k a, W służbie, s. 344.

35 Urzędnicy centralni i nadworni Polski XIV-XVIII wieku. Spisy, Kórnik 1992, nr 197; W. Z a witk ow sk a, W służbie, s. 369.

${ }^{36}$ A. S z y m c z a k o w a, Szlachta sieradzka, s. 51, 54.

37 Według A. S z y m c z a k o w e j (tamże, s. 52; za nią W. Z a w i t k o w s k a, W służbie, s. 353) zamiana między braćmi nastąpiła między 1462 a 1466 r., niemniej jeszcze 31 X 1465 dziedzicem Tuligłów był Jan Koniecpolski (AGZ XIII, nr 5934-5935, 5954, 5971).

38 Tamże, nr 6560-6563 (20 I 1463). 
tutejszymi dobrami, wydaje się to mało prawdopodobne. Zapewne zatem dopiero Doliński wkrótce po nabyciu majątku przystąpił do budowy kościoła. Byłoby to działanie zrozumiałe, jako że wówczas Tuligłowy stały się wsią rezydencjonalną, a to z kolei uzasadniałoby wzniesienie jakiejś świątyni, obsługującej mieszkańców dworu i wsi. W lipcu 1467 r. Jadwiga, wdowa po Janie z Łopuszki, z synami Mikołajem i Stanisławem dokonała zapisu dla kościołów w Rudołowicach (20 grzywien) i Tuligłowach (10 grzywien) $)^{39}$. Jest to pierwsza pewna wiadomość o tuligłowskim kościele. W sierpniu następnego roku (1468) pierwszą ratę w wysokości 10 grzywien podjął od donatariuszki pleban rudołowicki Piotr ${ }^{40}$. Najpewniej kościół tuligłowski był wówczas dopiero wznoszony i nie posiadał jeszcze osobnego duszpasterza. Skoro powstawał na terenie istniejącej już parafii rudołowickiej, musiał mieć zresztą status kościoła filialnego. O tym, że mamy rzeczywiście do czynienia z początkami świątyni w Tuligłowach, świadczą też kolejne zapisy na jej rzecz pochodzące z końca lat sześćdziesiątych i początku siedemdziesiątych oraz nieco późniejsza wiadomość o konflikcie miejscowego plebana z ludwisarzem z Łańcuta, co z kolei wskazuje na kompletowanie wyposażenia ${ }^{41}$. Kolejny legat na rzecz kościoła tuligłowskiego w wysokości 100 grzywien zapisał testamentem Jan Doliński² ${ }^{42}$ który nie doczekawszy się czteroletniego terminu wykupu Tuligłów, umarł między 16 IV 1469 a 19 VI 1470 r. ${ }^{43}$ Z kolei przed 1 III 1471 r. sumę 30 grzywien dla kościołów w Rudołowicach i Tuligłowach (charakterystyczne, że użyto tu liczby pojedynczej: pro ecclesia in Rudolouicze et Thuliglowy, co wskazuje na żywą pamięć jedności parafialnej) zapisała Fienna Bystrowska (Mzurowska) żona Jana, a córka wspomnianej Jadwigi z Łopuszki ${ }^{44}$. Dnia 15 II 1471 r. Mikołaj pleban w Tuligłowach pozwał do sądu biskupiego w Przemyślu Piotra plebana w Rudołowicach w sprawie jakichś zapisów testamentowych (in causa testamentaria) ${ }^{45}$. Zapewne spór dotyczył właśnie pieniędzy od Jadwigi lub Fienny, podjętych przez plebana rudołowickiego w okresie poprzedzającym erekcję osobnej parafii tuligłowskiej ${ }^{46}$. Zapewne jednocześnie

39 AAP 1, s. 111 (6 VII 1467). W tym tomie akt konsystorskich pomieszane i źle wydatowane są poszczególne składki i karty. Z analizy zgodności dni tygodnia i miesiąca oraz zapisów tej sprawy wynika, że zapis został dokonany właśnie w 1467 r.

40 AAP 1, s. 116 (16 VIII 1468); także tutaj data zrekonstruowana.

${ }^{41}$ W dniu 4 VII 1483 r. Marcin ludwisarz (fusor campanarum) z Łańcuta ustanowił swego syna Jerzego pełnomocnikiem w sprawie z plebanem i witrykami z Tuligłów (AAP 2, s. 105).

${ }^{42}$ Tu mowa o zapisanych 36 grzywnach (AAP 1, s. 368), ale ze zsumowania należności dla plebana tuligłowskiego uiszczanych w późniejszych latach wynika, że zapis opiewał na kwotę bliską 100 grzywien (AAP 1, s. 78, 137, 158, 368, 427-428; AAP 2, s. 89, 125, 139, 161, 248, 255, 293, 298, 405). Doliński poczynił też inne zapisy, m.in. dokumentem wystawionym w Przemyślu 22 VIII 1469 r. zapisał 400 grzywien dla klasztoru dominikanów w Przemyślu (AAP 8, s. 112-113; AGZ XVIII, nr 121), inny zaś legat przeznaczył dla kościoła w Czyżkach (AAP 1, s. 40).

${ }^{43}$ AGZ XIX, nr 28. W literaturze funkcjonuje data 17 X 1470, jako terminus ante quem śmierci sędziego (Urzędnicy województwa ruskiego XIV-XVIII wieku. Spisy, opr. K. Przyboś, Wrocław 1987, nr 1966, 1967).

${ }^{44}$ AAP 1, s. 21.

45 AAP 1, s. 20.

46 Jan z Bystrowic zobowiązał się 1 III 1471 r. złożyć w aktach konsystorza 30 grzywien zapisanych kościołom w Rudołowicach i Tuligłowach przez żonę Fiennę, z czego wywiązał się, 
z oddaniem do użytku kościoła, lub wkrótce potem, powstała szkoła parafialna, skoro tamtejszy nauczyciel (minister) wzmiankowany jest już w październiku $1471 \mathrm{r} \cdot{ }^{47}$ W tym też czasie musiało dojść do ustanowienia osobnej parafii w Tuligłowach, o czym przekonuje nomenklatura kościoła (ecclesia parochialis in Tuliglovi) ${ }^{48}$ i duchownych go obsługujących (Nicolaus plebanus de Thuliglovi) ${ }^{49}$, a także osobna gospodarka finansowa kontrolowana przez miejscowych witryków, pośrednio zaś tradycja mówiąca, że podział parafii rudołowickiej dokonał się za czasów plebana Piotra (consensus honorabilis Petri plebani Rudolovicensis pro dismembratione ecclesiae Tuligłowiensis a Rudołovicensi), choć z błędnym wskazaniem na osobę żyjącą w końcu XIV w. ${ }^{50}$ Pleban rudołowicki Piotr, jeden z dwóch noszących to imię, znany jest z lat $1468-1480^{51}$.

Tymczasem ksiądz Jakub Koniecpolski otrzymał korzystną propozycję kupna jego dóbr ruskich złożoną mu przez sąsiada, wojewodę sandomierskiego Dobiesława Kmitę z Dubiecka, pragnącego rozbudować własny kompleks majątkowy. Nie czekając więc zakończenia czteroletniego terminu, 8 I 1470 r. w Krakowie ustąpił Kmicie Rączynę, Tuligłowy i Zagórze w zamian za Karniowice w ziemi krakowskiej z dopłatą 1300 florenów węgierskich, przeznaczoną, jak to wyraźnie zaznaczono, na oczyszczenie dóbr ruskich $\mathrm{z}$ zastawów ${ }^{52}$. Zapis ten został następnie powtórzony 19 III 1471 r. w Przeworsku ze zamiennym dodatkiem: cum iure patronatus ecclesiae cuiuscumque, którego nie było w zapisce krakowskiej! $!^{53}$ Ogólnikowość (cuiuscumque) i formularzowy charakter tego zapisu nie mogą być dowodem, że zbywający miał na myśli kościół tuligłowski, choć w kontekście wyżej przytoczonych faktów wydaje się to bardziej niż prawdopodobne. Dodatkowo pozostałe dwie wsie, należące do parafii Pantalowice, nigdy nie miały na swym terenie kościołów.

Podsumowując dotychczasowe spostrzeżenia, stwierdzić należy, że miechowici przejęli kościół w Rudołowicach najpewniej dopiero w 1468 r. i zastali już na terenie tamtejszej parafii wzniesiony mniej więcej rok wcześniej kościół w Tuligłowach, który podlegał prawnie plebanowi rudołowickiemu. Wkrótce potem, w końcu 1470 lub na samym początku 1471 r., za zgodą plebana rudołowickiego wydzielona została osobna parafia tuligłowska.

Przed grudniem 1479 r. parafię tuligłowską objął nowy pleban Wawrzyniec, którego akta wzmiankują do listopada $1483 \mathrm{r}^{54}$

gdyż zapiska została w księdze skreślona (AAP 1, s. 21). Fienna była córką Jana z Łopuszki i jego żony Jadwigi. Umarła niewątpliwie bezpotomnie, gdyż mąż zwrócił 30 IV 1471 r. posag i wyprawę jej braciom Mikołajowi i Stanisławowi (AGZ XIX, nr 40).

47 Tomasz minister de Tuligłowy występuje od 25 X 1471 do czerwca 1476 r. (AAP 1, s. 34, 36, 150). Nie można jednak wykluczyć, że pod nazwą minister kryje się zwykły kościelny.

48 AAP 1, s. 368 (31 XII 1479).

49 AAP 1, s. 20 (15 II 1471).

50 AAP 166 (wizytacja biskupa H. Sierakowskiego), k. 143-143v, 145.

51 AAP 1, s. 116, 401; AGAD, dok. perg. 2620.

52 Starodawne prawa polskiego pomniki, t. II, wyd. A. Z. Helcel, Kraków 1870, nr 3997;

W. Z a w it k ow sk a, W służbie, s. 340.

${ }^{53}$ AGZ XIX, nr 34.

54 AAP 1, s. 368; AAP 2, s. 132. Niewykluczone, że Wawrzyniec pełnił swą funkcję jeszcze dłużej, gdyż 16 I i 21 V 1484 r. występuje pleban tuligłowski bez podania imienia 
W 1480 r. doszło do nieporozumień między plebanem rudołowickim Piotrem a bożogrobcami z Przeworska, którzy postawili mu jakieś zarzuty (certarum ut asseruit denunciacionum occasione) - nie wykluczone, że związane z uszczupleniem beneficjum rudołowickiego ${ }^{55}$. Ostatecznie Piotr został chyba odwołany, a na jego miejsce wybrano bliżej nieznanego Andrzeja, którego spotykamy w aktach z samego końca 1481 r. $^{56}$ Jego osoba, a może i sposób dokonania jego powołania, wzbudziły sprzeciw, motywany jakimiś krzywdami (super quibusdam iniuriis), Jana Mzurowskiego z Bystrowic, prawnuka fundatora kościoła rudołowickiego, który najwyraźniej kwestionował jego instalację, skoro użył wobec niego określenia presentatus, a nie plebanus. W efekcie Andrzej na początku 1482 r. został odwołany ${ }^{57}$. Byłby to ślad realizacji uprawnień, jakie pozostały w rękach Mzurowskich po przejęciu praw patronackich przez miechowitów. Tydzień później administrator diecezji przemyskiej nakazał wprowadzić po rezygnacji tegoż Andrzeja do kościoła w Rudołowicach i połączonego z nim kościoła (cum annexa altera) w Tuligłowach brata Grzegorza, prezentowanego przez prepozyta i konwent miechowski, jako prawdziwych patronów (veri patroni $)^{58}$. Warto przypomnieć, że w tym czasie plebanem w Tuligłowach był jeszcze wspomniany wyżej Wawrzyniec. Wydaje się prawie pewne, że to w tym właśnie czasie bożogrobcy dokonali wspomnianych wyżej falsyfikacji dokumentów datowanych na lata 1396 i 1446, podkreślających pierwotny filialny status kościołą tuligłowskiego i jego rzekome istnienie już przed cesją praw patronackich na rzecz miechowitów.

W październiku 1486 r. pleban rudołowicki Grzegorz wniósł do sądu biskupiego w Przemyślu skargę na prepozyta miechowskiego Jana, oskarżając go o to, że pod fałszywymi zarzutami usiłuje go pozbawić beneficjum plebana kościoła w Rudołowicach i kościoła filialnego w Tuligłowach (verus et legittimus plebanus ecclesiarum in Rudołowice tamquam matris et in Tuligłowy tamquam filiae ${ }^{59}$. Zwrot ten, tutaj po raz pierwszy użyty, jest wiernym powtórzeniem sformułowania z falsyfikatu datowanego na 1396 r., a powstałego w końcu XV w. Grzegorz, mimo trudności, utrzymał się na swym stanowisku (występuje jeszcze do 18 VII 1488 r.) ${ }^{60}$. Wygląda więc na to, że między 1483 a 1486 r. pleban tuligłowski Wawrzyniec przestał pełnić swą funkcję, być może umarł, a pleban rudołowicki przejął Tuligłowy pod swoją zwierzchność jako filię. Formalnie jednak status prawny kościoła tuligłowskiego był inny. O ile bowiem w źródłach miechowskich konsekwentnie wskazywano na filialny charakter tuligłowskiego kościoła, to z biskupich aktów instalacji z lat 1482 i 1489 wynika, że świątynia w Tuligłowych miała status połączonej (annexa) $\mathrm{z}$ rudołowicką ${ }^{61}$. Zgodnie $\mathrm{z}$ prawem kanonicznym $\mathrm{w}$ ten właśnie sposób określano

(AAP 2, s. 139, 161). Dnia 5 III 1485 należność dla kościoła podjął witryk Jerzy Gut, 5 III 1486 - witrycy, 24 III tr. - pleban i witrycy, 14 III 1487 - znowu sami witrycy, a 9 X 1489 r. - rektor i witrycy (AAP 2, s. 191, 248, 255, 293, 405).

${ }_{55}$ AAP 1, s. 401 (3 VII 1480).

56 AAP 2, s. 6 (6 XII 1481).

57 AAP 2, s. 26 (16 III 1482).

58 AGAD, dok. perg. 2639 (22 III 1482).

59 AAP 5, s. 3v (3 X 1486).

${ }^{60}$ AAP 2, s. 351.

${ }^{61}$ Dnia 22 III 1482 r. administrator diecezji przemyskiej Maciej z Kleparza nakazał wprowadzenie brata Grzegorza do kościoła w Rudołowicach cum annexa altera in Thuliglivi 
świątynie połączone na równych prawach, zachowujące swoje przywileje, ale zarządzane przez jednego plebana. Takie połączenie kościołów znało średniowieczne prawo kanoniczne co najmniej od XIII w. Jak wyjaśniał francuski kanonista Petrus Rebuffus w swym dziele Praxis beneficiorum z 1599 r.: Tertio fit unio duarum ecclesiarum, ut utraque remanent - - parrochialis, sicut erat, et tunc dicitur aeque principalis utraque ecclesia, sed unus erit - - rector utriusque ecclesiae, et tunc quaelibet sua habebit privilegia et statuta ${ }^{62}$. W praktyce życia codziennego przeważył jednak model forsowany przez miechowitów i w następnych latach kościołem tuligłowskim zarządzali podlegli plebanowi rudołowickiemu administratorzy zwani prebendarzami. Tak przynajmniej wynika z nieco późniejszego źródła, opisującego jednak sytuację z końca XV w.: licet ex consuetudine dudum observata et pro lege tenta omnes plebani in Rudolowycze predecesores moderni matrici in ecclesie in Rudolowycze parochiali per se, flie vero eiusdem in Tulyglowi consistenti per fratres sui ordinis de facto presbiteros divina peragentes officia et parochianis ecclesiastica ministrando sacramenta per multos annos optima pace gudendo servierunt ${ }^{63}$. Z lat 1490-1492 mamy wiadomości o prebendarzu tuligłowskim Jerzym ${ }^{64}$, jego następca zaś Jan tytułował się (1495-1497) plebanem ${ }^{65}$.

Zaniedbanie obowiązków plebańskich względem kościoła tuligłowskiego stało się zapewne w 1489 r. przyczyną konfliktu między nowym plebanem a kmieciami z Tuligłów, którzy w efekcie zaprzestali oddawania mesznego ${ }^{66}$. W tym samym czasie przestali oddawać daniny (annone) i meszne także kmiecie z Węgierki, za co zostali obłożeni ekskomuniką przez biskupa Jana z Targowisk (zm. 1492) i pozostawali pod nią około roku ${ }^{67}$. Konflikt, jak można się domyślać, zażegnano, nakazując plebanowi ustanowienie w Tuligłowach duchownego (prebendarza) stale obsługującego tamtejszą społeczność. W Wielkim Poście 1491 r. Jerzy dzierżawca (arendarius capellae) beneficjum w Tuligłowach, późniejszy wikariusz w Pruchniku, za zgodą biskupa Jana i wiedzą plebana rudołowickiego Jana, uwolnił tamtejszych kmieci od ekskomuniki ${ }^{68}$. Natomiast sprawę zaległych świadczeń uregulowała ugoda, w związku z którą została

(AGAD, dok. perg. 2639), a 14 I 1489 r. biskup przemyski Jan z Targowiska nakazał wprowadzić brata Jana z Miechowa na beneficjum otrzymane po ustąpieniu Grzegorza (AGAD, dok. perg. 2649). Jan wzmiankowany jest jako pleban 27 II 1489 r. (AAP 2, s. 376).

${ }_{62}$ Cytuję za: W. U r u s z c z a k, Unio regnorum sub una corona non causat eorum unitatem. Unia Polski i Litwy w Krewie w 1385 r. Studium historyczno-prawne, Kraków 2017, s. 14-19.

${ }_{63}$ AAP 8, s. 211-212.

${ }^{64}$ AAP 3, k. 75v, 110v, 120, 120v, 127, 127v; AAP 8, s. 74-75.

65 AAP 3, k. $179 \mathrm{v}, 266 \mathrm{v}$.

${ }^{66}$ AAP 2, s. 422 (22 I 1490).

${ }^{67}$ S. C y nar ski, F. K i ry k, Jan z Targowisk, w: Polski słownik biograficzny, t. X (1962-1964), s. 484.

68 Mimo wyrażenia zgody na zdjęcie ekskomuniki z kmieci, pleban Jan pozwał o to Jerzego do sądu biskupiego. Sprawa zakończyła się uwolnieniem pozwanego od zarzutów (AAP 8, s. 74-75 - 11 X 1493). Prawie równolegle, być może w związku z wygaśnięciem kontraktu dzierżawy beneficjum tuligłowskiego, pleban wytoczył mu na początku $1492 \mathrm{r}$. proces o remont plebanii w Tuligłowach oraz o zasiewy na tamtejszych gruntach i w ogrodach plebańskich, określone w kontrakcie dzierżawy kościoła. Dnia 3 II 1492 r. kapłan Jerzy, arendarius capelle in Thuliglowy, ustanowił swego pełnomocnika. Sprawa toczyła się do 11 X 1493 r. i skończyła się uwolnieniem Jerzego od roszczeń Jana (AAP 3, k. 75v, 110v, 120, 120v, 127, 127v). 
dokonana na samym początku tegoż 1491 r. przez Stanisława Derszniaka dziedzica Tuligłów darowizna sadzawki dla plebanów rudołowickich i tuligłowskich w zamian za obowiązek odprawiania mszy za dusze jego rodziców, za niego samego i jego żonę ${ }^{69}$. Nadanie sadzawki jednocześnie dla dwóch kościołów (plebanów) świadczy o uznaniu przez dziedziców podporządkowania świątyni tuligłowskiej plebanom rudołowickim. W następnych latach kościół tuligłowski funkcjonował jednak jako parafialny (ecclesia parochialis in Thuliglowy), a obsługujących go duchownych określano jako plebanów ${ }^{70}$.

W 1503 r. wspomniany pleban rudołowicki Jan wytoczył proces całej społeczności kmiecej Tuligłów, która po zniszczeniach kolejnego najazdu (1502?) znowu odmówiła mu oddawania mesznego z powodu nieodprawiania mszy w Tuligłowach. Wyrokiem sądu nakazano plebanowi odprawianie na zmianę mszy w obu kościołach (ad peragendum divina officia et ministrandum parochanis dictarum ecclesiarum sacramenta eclesiastica--alternatis vicibus in dictis ecclesiis $)^{71}$, co jest jeszcze jednym dowodem równoprawności obu kościołów ${ }^{72}$. Sytuacja taka trwała także w pierwszej połowie XVI w., chociaż kościół tuligłowski spadł do roli kaplicy (sacellum $)^{73}$. Niemniej plebani rudolowiccy tytułowani byli także plebanami tuligłowskimi ${ }^{74}$.

Wspomniany najazd tatarski w 1502 r. spowodował spustoszenie i zniszczenie obu kościołów. Wobec zbliżającego się zagrożenia pleban rudołowicki miał zdeponować u mieszczanina przemyskiego Jana Orlińskiego dokumenty kościoła tuligłowskiego, o których zwrot upomniał się w $1504 \mathrm{r}^{75}$ Niewątpliwie nie były to jednak omawiane wyżej dokumenty kościoła rudołowickiego, zachowane po dziś dzień, z których ten z 1396 r. przedstawiano później jako fundacyjny kościoła tuligłowskiego. Deponowano najpewniej właściwe dokumenty fundacji i erekcji odrębnego kościoła w Tuligłowach. Nie jest zresztą pewne, czy do zdeponowania rzeczywiście doszło, gdyż Orliński się do tego nie przyznał. Być może dokumenty zostały wtedy celowo zniszczone jako sprzeczne z polityką konwentu. W wizytacji w 1646 r. zanotowano, że kościół tuligłowski fundationis litteras habet nullas $^{76}$. Natomiast w trakcie kolejnej w 1699 r. zapisano już, że oryginał fundacji przechowywany jest w archiwum klasztoru miechowskiego ${ }^{77}$.

${ }^{69}$ AAP 2, s. $492-493$ (7 I 1491). Wiosną 1493 r. pleban Jan pozwał niejakiego Daniłę z Rudołowic o wyłowienie ryb z sadzawki plebańskiej w Tuligłowach (AAP 3, k. 105).

70 AAP 4, s. 84 (9 I 1495), AAP 3, k. 179v (9 II 1495), 266v (11 IX 1497).

${ }^{71}$ AAP 8, s. 203, 211-212.

${ }^{72} \mathrm{O}$ wzajemnych relacjach między kościołami na terenie jednej parafii w zakresie obowiązków duszpasterskich zob. I. S k i e r s k a, Obowiązek mszalny w średniowiecznej Polsce, Warszawa 2003, s. 81-84.

73 Dnia 1 VIII 1543 r. prepozyt miechowski i konwent prezentowali Jana ze Skaryszewa na kościół w Rudołowicach i kaplicę (sacellum) w Tuligłowach, collationis et iurispatronatus nostri, po śmierci Jakuba z Lelowa (AGAD, dok. perg. 2730). Podobnie 18 V 1548 r. (AGAD, dok. perg. 2739).

${ }_{74}$ W 1554 r. występuje Andrzej pleban w Tuligłowach (AAP 19, k. 216v), a w 1559 Eustachy pleban w Tuligłowach (AAP 24, k. 23-23v). Obaj byli jednocześnie plebanami rudołowickimi.

75 AAP 8, s. 214.

76 AAP 64 (wizytacja biskupa Piaseckiego, 1646), s. 34.

77 AAP 155 (wizytacja biskupa Denhoffa, 1699), k. 94. Niewątpliwie miano na myśli dokument z 1396 r., oblatowany kilkakrotnie jako akt fundacyjny kościoła tuligłowskiego. 
W maju 1558 r. Tuligłowy znalazły się w rękach dworzanina królewskiego Stanisława Drohojowskiego ${ }^{78}$. Nowy dziedzic znany był w ziemi przemyskiej z konfliktów z Kościołem katolickim ${ }^{79}$. Jest zatem wielce prawdopodobne, że to właśnie w tym czasie doszło do sprofanowania kościoła w Tuligłowach (per haeresim ab annis prophanata multis suo legitimo pastore destituta esset) ${ }^{80}$. Dopiero w $1582 \mathrm{r}$. jedyny spadkobierca całej fortuny Derszniaków, Stanisław syn Walentego, odkupił od Drohojowskiego Tuligłowy z dworem, folwarkiem oraz cum - - iure patronatus praesentandi parrochi seu praebendarii in praefatis bonis existentibus ${ }^{81}$.

W 1596 r., po kilkudziesięcioletniej przerwie, pojawił się w Tuligłowach nowy pleban, miechowita Zachariasz Kulka z Żarnowa (były pleban w Zarzeczu) ${ }^{82}$. Z niewiadomych jednak przyczyn dopiero dwa lata później został on oficjalnie instalowany ${ }^{83}$. Jest to niewątpliwie moment ustanowienia nowej (lub raczej przywrócenia starej) parafii w Tuligłowach. Przy okazji dowiadujemy się, że nowy pleban był prezentowany przez dziedzica Rokietnicy i Tuligłów Stanisława Derszniaka, jedynego patrona tego kościoła (eiusdem ecclesiae parochialis unici et legittimi patroni et collatoris). W 1606 r., po śmierci Kulki, wprowadzono do kościoła tuligłowskiego kolejnego miechowitę Gabriela z Pajęczna prezentowanego tym razem przez prepozyta miechowskiego, biskupa włocławskiego i pomezańskiego Piotra Tylickiego oraz Stanisława Derszniaka, określonego jako patron (supradictae ecclesiae legittimum patronem et collatorem $)^{84}$. Z kolei w 1612 r., po śmierci Gabriela, wprowadzono na parafię miechowitę Adama Markowskiego, prezentowanego przez prepozyta miechowskiego Henryka Firleja, referendarza koronnego i Stanisława Derszniaka, przy czym obaj nazwani zostali patronami (legittimorum patronum et collatorum supradictae ecclesiae) ${ }^{85}$.

Po śmierci Derszniaka, która nastąpiła między 1612 a 1617 r., w okresie małoletniości jego synów, miechowici całkowicie przejęli patronat w swoje ręce ${ }^{86}$. W $1620 \mathrm{r}$.

7810 V 1558 Piotr Derszniak zastawił Czelatyce i Tuligłowy za 6600 fl. Stanisławowi Drohojowskiemu - Центральний державний історичний архів України Львів (dalej cyt.: CDIAUL), fond 14, opis 1 (dalej cyt.: Przemyśl Z.) 17, s. 915-920.

79 Przemyśl Z. 23, s. 27-28 (tekst urwany). F. P a w ło w s ki, Premislia sacra, s. 272 273, 296-297; S. B o d n i a k, Drohojowski Stanisław, w: Polski słownik biograficzny, t. V (1939-1946), s. 388; T. Śli w a, Diecezja przemyska w połowie XVI wieku, Przemyśl 2015, s. 233-235. Drohojowski od 1557 przestał oddawać dziesięciny z ról dworskich w Drohojowie należne kościołowi w Radymnie (AAP 25, k. 5-5v), w 1556 zagarnął dziesięcinę snopową z Chłopic należną kościołowi w Łowcach (AAP 24 k. 30v), a w 1559 r. „tknięty herezją”, wraz ze Stanisławem z Opatowca przybyłym z Pińczowa żonatym księdzem, sprofanował kościół w Jaćmierzu, za co został ekskomunikowany (AAP 22, k. 247v-251); proces z plebanem z Łowców ciągnął się w 1. 1568-1571 (CDIAUL, fond 12, opis 1 [dalej cyt.: Przeworsk Z.] 33, s. 55-62, 263, 637).

${ }^{80}$ Z wyroku oficjała przemyskiego z 3 II 1623 r. w sprawie między plebanem tuligłowskim Adamem Nockowskim (Nockovius) a Janem Korwinem plebanem pruchnickim o meszne z Węgierki (AAP 1778 [Akta parafii Tuligłowy], s. 59).

${ }_{81}$ Przemyśl Z. 40, s. 1201-1206; Przeworsk Z. 9, s. 690-692; Przeworsk Z. 10, s. $594-$ 601 (23 I 1582).

82 AAP 27, k. 129-130, 131v-132v, 676 (18 III 1596).

83 AAP 31, k. 9 (27 VII 1598).

${ }^{84}$ AAP 31, k. 221v-222 (14 IV 1606).

85 AAP 32, k. 15v-16 (27 VI 1612).

${ }^{86}$ Derszniak umarł przed 22 III 1617 r. (AAP 143, k. 89v-90). 
nowego plebana Adama z Nockowej (Nockovius) prezentowali już wyłącznie prepozyt Maciej Łubieński i bracia z konwentu miechowskiego ${ }^{87}$. Derszniakowie jednak nie wyzbyli się swoich praw, o czym dobitnie świadczy zapis z aktu podziału dóbr, dokonanego 22 III 1622 r. Stanisławowi Derszniakowi przypadły wówczas m.in. Tuligłowy oraz ,ius patronatus w Tuligłowach zupełnie cum praesentatione parochy do kościoła tuligłowskiego" "88. Podobnie w 1626 r., gdy Stanisław ustąpił swój dział bratu Jackowi, uczynił to cum - - iure patronatus praesentandi tam ecclesiae Romanae, quam ritus Graeci ${ }^{89}$. Mimo tego stałego poczucia posiadania praw kolatorskich przez kolejnych dziedziców Tuligłów, także i następne prezenty na tamtejszą parafię odbywały się już bez ich udziału ${ }^{90}$. W wizytacji 1636 r. zapisano zaś, że patronat przysługuje konwentowi miechowskiemu¹.

Reasumując powyższe rozważania, uznać należy, że kościół w Tuligłowach został wzniesiony zapewne ok. 1467 r. przez chorążego przemyskiego Jana Dolińskiego, wkrótce po nabyciu przezeń tej wsi. Niedługo potem, ok. 1470 r., doszło do ustanowienia w Tuligłowach nowej parafii, wydzielonej z dotychczasowej rudołowickiej. Szczupłość dochodów nowego beneficjum (opartego jedynie na mesznym, dziesięcinie z ról dworskich i innych daninach oraz legatach okolicznej szlachty) spowodowała, że ok. 1482 r. bożogrobcy na podstawie falsyfikatów datowanych na 1396 i 1446 r., wskazujących na rzekomą pierwotną podległość tego kościoła Rudołowicom, przejęli go w swoje ręce za aprobatą biskupów przemyskich, traktując jako filię rudołowickiego ${ }^{92}$. Fakt ten spowodował, że z czasem także Tuligłowy uważać zaczęto za podległe miechowskiemu patronatowi. W praktyce kościół tuligłowski znajdował się pod zarządem sprawowanym przez niższych duchownych. Stan taki trwał do drugiej połowy XVI w., kiedy to kościół tuligłowski został zamieniony na zbór. Dopiero około 1596 r. został restytuowany katolikom, ponownie jako parafialny, przez dziedzica Stanisława Derszniaka, jako jedynego i prawnego patrona. Jest wielce prawdopodobne, że Derszniak wzniósł przy okazji od podstaw nowy drewniany kościół i z tego też powodu stał się jego patronem ${ }^{93}$. Roszczenia jednak wkrótce podnosili bożogrobcy miechowscy, którzy w końcu ponownie uznani zostali za jedynych patronów kościoła.

87 AAP 32 k. 379v-320 (20 XI 1620).

${ }^{88}$ CDIAUL, fond 13, opis 1 (dalej cyt.: Przemyśl Gr.) 82, s. 467.

89 Przemyśl Gr. 84, s. 183-186 (18 II 1626).

90 Dnia 7 X 1637 r. prepozyt miechowski Piotr Gembicki, biskup przemyski i podkanclerzy koronny wraz z całym konwentem jako kolatorzy po śmierci Adama z Nockowej prezentowali miechowitę Stanisława Dłuskiego (AAP 36, k. 188v-189).

${ }^{91}$ AAP 143, k. 207-207v. Z kolei w wizytacji z 1744 r. zapisano: Ius patronatus a tempore immemorabile huius ecclesiae est conventui Miechoviensi canonicorum regularium sanctissimi Sepulchri Hierosolimitani custodum cessum et ipsi de gremio suo rectorem eligunt, sed qualiter hoc ius sibi vendicunt in praesenti visitatione iustificatum non est, allegantur in archivo conventus Miechoviensi authentica super eo documenta extare, quae ad praesens non sunt producta, nunquam tamen ab immemorabili in iure suo a quopiam impetebantur (AAP, 166, k. 143v).

92 AAP 5, k. 3v; Aneks nr 3.

${ }^{93} \mathrm{O}$ takim sposobie uzyskiwania praw patronackich zob. P. L a n d a u, Ius patronatus. Studien zur Entwicklung des Patronats im Dekretalenrecht und der Kanonistik des 12. und 13. Jahrhunderts, Köln-Wien 1973, s. 16-18. 
Działania konwentu względem opisywanych tu kościołów nie są wyjątkiem. W podobny sposób powiększyli oni uposażenie kościoła w Urzejowicach, a może nawet $\mathrm{w}$ ogóle weszli w jego posiadanie, a także próbowali rozszerzyć pierwotne nadanie we wsi Świętoniowa Wola ${ }^{94}$. Dzieje opisywanych tu kościołów w Rudołowicach i Tuligłowach ilustrują, jak skomplikowana była historia struktur Kościoła rzymskokatolickiego na Rusi Czerwonej i jak wnikliwie należy analizować początki każdej tutejszej parafii.

\section{ANEKS}

1.

$21 \times 1393$

Mikołaj Mzurowski z Rudołowic uposaża ufundowany przez siebie kościół parafialny w tej wsi.

Or.: AGAD, dok. perg. 2417, pergamin; pasek pergaminowy po pieczęci; na odwrociu noty z XVI w.

Kop.: 1. AAP 12, k. 126-126v, wpis z 6 X 1536 wedtug or.; 2. AAP 1777, s. 14-15, wedtug kopii 1.

Wyd.: 1. S. Nakielski, Miechovia, s. 345; 2. ZDM IV, nr 1107, wedtug kopii.

Reg.: AAP 143, k. 202.

In nomine Domini amen. Nos Nicolaus Msurowski heres in Rudolowicz notum facimus, quibus expedit, universis, quod mente sana et bona deliberatione, in salutem et salubre remedium anime nostre nostrorumque legittimorum ecclesiam in villa nostra Rudolowicz ad laudem et gloriam Dei Omnipotentis Eiusdemque Gloriose Genitricis ac omnium sanctorum nec non ad honorem sancti Nicolai confessoris, divi patroni in eadem specialiter deputati statuimus et fundamus. Cui itaque ecclesie damus, assignamus et incorporamus infrascripta, videlicet decimam manipularem de tota aratri cultura in villa prenominata, item alterum dimidium mansum, ${ }^{a}$-sex stadios pro preposito $^{-b}$ templi iuxta piscinam ${ }^{c-}$ cum area $^{-d}$ iuxta templum olym Rutheni et unum integrum mansum iuxta ${ }^{e}$ piscinam vicinam versus Jaroslawiam situatum, item pratum speciale, item thabernam in medio ville prescripte situatam, item piscinam ad construendum loco pociori ubicumque poterit locari, insuper missalia nec non et cetera alia in nostris quattuor villis subscriptis, videlicet Rudolowicze, Bystriowicze, Wøczkowicze ${ }^{f}$, Thuliglowy, secundum modum, consuetudines et qualitates ecclesiarum districtus Landishutiensis, Jaroslawiensis. Hec omnia et singula premissa damus et incorporamus ecclesie memorate ${ }^{g}$ seu Rudolowiensibus rectoribus ${ }^{-h}$ omnibus et singulis in eadem. Ut autem dotatio pretacta maneat rata, grata atque firma et in sempiternum Deo annuente duratura, litteram presentem sigilli nostri munimine roboramus. Actum et datum sub anno incarnationis Domini millesimo trecentesimo nonagesimo tercio in die Undecim milia virginum et martirum gloriosarum, presentibus venerabilibus et discretis ac nobilibus viris, scilicet domino et domino Mathia divina et Apostolice Sedis providencia episcopo Przemisliensi,

94 ZDM V, nr 1255, 1315; T. M. Tr a j d o s, Miechowici na ziemi przemyskiej, s. 67-98; M. S t a r n a w s k a, Między Jerozolimą a Łukowem. Zakony krzyżowe na ziemiach polskich w średniowieczu, Warszawa 1999, s. 101, przyp. 304. 
${ }^{i}$-Johanne preposito Premisliensi ${ }^{-j}$, Mykulca notario domini episcopi premissi, Petro plebano Jaroslawiensi, Ptaczkone herede de Nenkowicz, Stachnikone de Czelaticz herede, nec non et quampluribus viris fide dignis.

${ }^{a-b}$ W kopiach: scilicet medium ex opposito; $w$ wizytacji 1636 r. zapisano: dimidium mansum ex opposito templi iuxta piscinam (AAP 143, k. 202-202v), cytujac wersje przekazana przez kopię; W słowie stadios końcówka poprawiona po wytarciu pierwotnego -orum, potem wytarte słowo ex, w miejsce którego wpisano pro, a w słowie preposito poczatek poprawiony po wytarciu pierwoptnego -op; pierwotnie było więc: sex stadiorum ex opposito; we wszystkich kopiach jest: scilicet medium ex opposito, a w wizytacji $1636 \mathrm{r}$.: dimidium mansum ex opposito templi (AAP 143, k. 202-202v), cytujac wersje przekazana przez kopię; ${ }^{c-d}$ kop.: in area, wyd. 1: cum area, ${ }^{e}$ kop.: ultra, ${ }^{f}$ wyd. 1: Woczkowice alias Wiaczkowice, ${ }^{g-h}$ kop.: in Rudolovycze seu rectoribus, ${ }^{i-j} w$ wyd. 1 brak.

\section{2.}

Przemyśl, 28 IV 1394

Maciej biskup przemyski za zgoda kapituły katedralnej nadaje kościołowi parafialnemu $w$ Rudołowicach dziesięciny $z$ ról kmiecych $w$ Rudołowicach $i$ Tuligłowach.

Or.: AGAD, dok. perg. 2418, pergamin; dwa sznury z czerwonego i zielonego jedwabiu, na jednym zachowana pieczęć biskupa Macieja; na odwrociu noty z XVI w.

Kop.: 1. AAP 12, k. 127-127v, wpis z 6 X 1536 wedtug or.; 2. AAP 1777, s. 17-18, wedtug kopii 1.

Wyd.: 1. S. Nakielski, Miechovia, s. 345-346; 2. ZDM IV, nr 1111.

Reg.: AAP 143, k. 202v.

In nomine Domini amen. Ad perpetuam rei memoriam. Mathias divina et Apostolice Sedis providencia episcopus Premisliensis notificamus, tam presentibus, quam futuris, presencium noticiam habituris, quibus expedit, universis, quod attendentes et debita mentis solicitudine perpendentes redditus et proventus ecclesie parrochalis in Rudolouicze nostre dioecesis Premisliensis adeo fore tenues et exiles, quod non sufficiunt, nec sufficere possunt ad onera eiusdem ecclesie comode supportanda, moti itaque atque ducti pietatis affectu ad honorem et laudem Omnipotentis Dei et Genitricis eius Marie Virginis Gloriose, nec non b. Nicolai confessoris atque pontificis gloriosi, in cuius honore dicta ecclesia dotata et fundata dinoscitur per nobilem virum dominum Nicolaum Mzurowsky et per nos dedicata, tractu diligenti cum nostro capitulo habito et ipsius consensu accedente decimam tocius ville predicte, nec non ville Tuligloui in districtu Premisliensi site ipsi ecclesie et eius rectori, qui pro tempore fuerit, damus, incorporamus et assignamus temporibus perpetuis duraturis, ut idem rector ecclesie, qui pro tempore fuerit, ut premittitur eandem decimam in Rudolouicze, necnon in Tuligloui pro se et pro ecclesia sua recipiendi, tollendi singulis annis plenam et liberam habeat facultatem. In cuius rei testimonium et evidenciam pleniorem nostrum et nostri capituli sigilla presentibus sunt appensa. Datum et actum in Premislia, ipso die Vitalis anno Domini millesimo tricentesimo nonagesimo quarto. 
3.

Falsyfikat

1396

Maciej biskup przemyski na prośbę Mikołaja Mzurowskiego potwierdza uposażenie kościoła w Rudołowicach $i$ jego filii w Tuligłowach dziesięcinami z ról dworskich, gdziekolwiek w przyszłości powstałby dwór, oraz ról kmiecych doń należących, a także wszelkimi daninami kmiecymi i mesznym we wsiach Rudołowicach, Więckowicach, Bystrowicach, Tuligłowach, Wegierce i jej nowo lokowanej Woli.

Rzekomy or.: AGAD, dok. perg. 2425, pergamin; nacięcie po pasku od jednej pieczęci; na odwrociu noty z XVI i XVII w.

Kop.: 1. AAP 12, k. 126v-127, wpis z 6 X 1536 (wedtug or); 2. AAP 143, k. 99-99v, wpis z 23 I 1623 (wedlug or.); 2. AAP 1777, s. 16-17, wedlug kopii 1; 4. CDIAUL, f. 14, op. 1, spr. 246, s. 2117-2120, wpis 4 X 1779 (wedtug kop. 2), tytut: Oblata fundationis pro ecclesia in Tuligłowy sita.

Wyd.: 1. S. Nakielski, Miechovia, s. 346; 2. AGZ VI, nr 7, wg odpisu z kop. 2. Reg.: AAP 143, k. 202v.

Nobis Mathie, Dei gracia episcopo Premisliensi, piie propter Deum extitit suplicatum pro honorabili et idoneo Petro, capelano nostro et cancelarie nostre protunc notario, per generosum ac nobilem Nicolaum Mzwrowsky, heredem de Rudolowicze legitimumque successorem, una cum ipsius liberis in villas Rudnyky, Strzelcycze, Tvlyglowy, Wnczkowicze; audiens igitur honorabilis Petrus capellanus noster certificarique volens, omnino de proventibus prefate eclesie in Rudolowicze ac ipsius filye in Twlyghlowy generosum ac nobilem Nicolaum Mzwrzowszky coram nobis ac honorabilibus et circumspectis Johanne preposito eclesie Premisliensis, Petro plebano Jarosszlaviensi, Mikulka eciam notario nostro, nobili Pthaczkonye herede de Jankowycze ceterisque pluribus fide dignis, non obstante privilegio fundacionis paulo ante dato, nostro ex consensu clare exquesivit, quod et decuit prelacionis nostre ex officio. Qui generosus Nicolaus ob spem salutis suae et suorum successorum bene deliberatus assignavit et dedit in perpetuum, prout ipse et antecessores sui tenuit et tenuerunt, honorabili Petro plebano suo et suis successoribus decimas manipulares post omnes curias suas ubicunque curia sua locata fuerit aut kmethonum cultura ipsum condecernens ${ }^{a}$ una cum kmethonum annonis, missalibus ${ }^{b}$, caeterisque proventibus videlicet in Rudolowycze, Vynczkowicze, Byszthrzyowycze, Tuliglowy et Wangerka eiusdem ville Wola nouiter situata, amborum igitur ex consensu videlicet generosi Nicoali iam dicti et honorabilis Petri plebani simulque et rogatu praesens scriptum in robur perpetuum sigilli appensione roborari non distulimus sub anno domini millesimo trecetesimo nonagesimo sexto.

${ }^{a}$ Wyd. 1: concernens, $\quad{ }^{b}$ Wyd. 2: salis. 
4.

Przeworsk, 2 V 1446

Bracia Jan stolnik przemyski i Mikołaj Mzurowscy z Janem i Mikołajem, synami Jana, oddają wieczyście kościoły parafialne w Rudołowicach i Tuligłowach klasztorowi miechowskiemu, zachowujac sobie prawo prezenty wskazanych przez konwent kandydatów.

Kop.: Kraków, Archiwum Narodowe, Terrestria Cracoviensia nova, t. 79, s. 334335, wedtug wyd. 1; 2. AAP 1777 (XVIII w.), zapewne wedtug wyd. 1; 3. Kraków, Biblioteka Książat Czartoryskich, rkp. 2892 (XVIII w.), s. 17, wedtug wyd. 1.

Wyd.: 1. S. Nakielski, Miechovia, s. 480-481; 2. ZDM VII, nr 2504.

In nomine Domini amen. Ad perpetuam rei memoriam. Nos Iohannes de Mszurow dapifer Premisliensis et Nicolaus, fratres germani, Iohannes et Nicolaus filii nostri, de Rudolowice dioecesis Premisliensis significamus universis, quibus expedit, tam praesentibus, quam futuris, praesentes litteras nostras inspecturis, quod attendentes zelum et fervorem divinae laudis profectumque devotionis et amplitudinem domus Dei et pietatis studium, quibus fratres religiosos monasterii in Miechow ordinis s. Sepulchri Dominici Hierosolymitani sub regula divi Augustini novimus insigniri, cupientesque nostram ac nostrorum antecssorum et successorum salutem misericorditer divinitius promovere, unanimi consensu omnium nostrorum fratrum ac filiorum praedictorum praefatae dioecesis Premisliensis ecclesias parochiales in Rudolowice ac etiam in Tuliglowy in dicta dioecesi Premisliensi constitutas ipsi monasterio Miechoviensi et fratribus donamus, incorporamus ac in perpetuum resignamus nulla occasione impedire ac prohibere, ius praesentandi fratres ad easdem ecclesias etiam ipsum regimen ipsis praeposito videlicet protunc et fratribus condescendendo et incorporando temporibus aeviternis. Ita tamen, quod nos et successores nostri legitimi fratres de monasterio praedicto Miechoviensi debebimus extunc in rectores bonos et valentes etiam exemplares, quos ipsi dominus praepositus cum suis fratribus tenebuntur ad investiendum canonice et confirmandum loci ordinario temporibus perpetuis mittere et praesentare, ut ex hoc inter nos et successores nostros et ipsos praepositum et fratres eius ac successores ipsorum vinculum caritatis augeatur et crescat. In casu, si praedicti fratres per ipsos praepositum et fratres de Miechow ad praedictas ecclesias gerendas missi et praesentati et per loci ordinarium confirmati boni et valentes non extiterint, extunc ipse dominus praepositus una cum fratribus suis et successores, fratres ex causis rationabilibus ad monasterium ipsorum revocare debent et ecclesiis praefatis villarum nostrarum alios fratres loco ipsorum, quos nos duxerimus cum successoribus nostris legitimis ad regendum easdem ecclesias et per [loci] ordinarium investiendum praesentare debent temporibus perpetuis. Proventus quoque ad easdem ecclesias antiquitus assignatos rectoribus successive institutis de fratribus praedictis Miechoviensis monasterii assignantes et perpetuo confirmantes. In cuius rei testimonium sigillum nostrum praesentibus est appensum. Acta et data in monasterio Preuorscensi feria secunda in crastino ss. Philipi et Iacobi apostolorum anno Domini millesimo quadringentesimo quadragesimo sexto, praesentibus honorabilibus dominis: Iohanne praeposito de Przeworsko, Iacobo de Gacz plebano, Conrado de Rokitnica, Andrea vicario de Prochnik, Petro vicario de Rokitnica et nobili Iohanne de Turkowice, testibus ad praedicta specialiter vocatis et rogatis. 
5.

Radymno, 23 czerwca 1448

Piotr biskup przemyski zaświadcza, że Jan Gołuchowski nadał kościołowi parafialnemu $w$ Rudołowicach dziesięciny z ról dworskich $w$ Roźwienicy oraz meszne $z$ wsi Roźwienica $i$ Wola Roźwienicka, 2 grzywny czynszu oraz kielich srebrny $i$ ornat z przynależnościami.

Or.: AGAD, dok. perg. 2564, nacięcia po pasku od 1 pieczęci. Na marginesach streszczenia z XVII w., na odwrociu streszczenia $i$ noty z XVII-XVIII $w$.

Wyd.: 1. S. Nakielski, Miechovia, s. 482-483; 2. ZDM III, nr 790.

In nomine Domini amen. Petrus Dei gratia episcopus Premisliensis significamus tenore presencium universis, tam presentibus, quam futuris, quomodo in nostra ac notarii et scribe causarum aule nostre testiumque infrascriptorum presenci constitutus personaliter nobilis Johannes Goluchowsky de Roszdrwenicza animo ipsius optime deliberato ultroneeque $^{a}$ et sponte, nullo scrupulo contraveniente ${ }^{b}$, dedit, donavit, assignavit pro ecclesia parrochiali in Rudolowycze et eius rectore Nicolao moderno, pro eiusque successoribus inperpetuum et in ewm, sive sit regularis, sive irregularis, decimam manipularem post araturas eterne ${ }^{c}$ in Roszdrwenicza cuiuslibet grani et annonas siliginis et avene de villis de eadem Roszdrwenicza ac alia Wolya Roszdrweniczska item duas marcas minute ${ }^{d}$ pecunie de censu proveniente ${ }^{e}$ in Roszdrwenicza, unam ad festum s. Johannis Baptiste Natalis, aliam ad festum s. Martini se continue et immediate festa sequencia singulis annis. Item unum calicem argenteum et ornatum cum attinenciis debet dare pro divinis celebrandis. Racione et occasione cuius donacionis et assignacionis plebanus et sui successores pro tempore existentes debet et debent duas missas legere singulis septimanis singulis annis, unam feria quatra pro defunctis, aliam sabbato de Assumpcione B. Marie Virginis, aut de tempore. Et ibif eadem ecclesia in Rudolowycze altare speciale debet deputari per plebanum et colatores pro dictis missis celebrandis. Itaque tenentur ambe partes et eorum successores, tam plebanus, quam Goluchowski, tenere et sint astricti sub pena excommunicacionis in eorum quemlibet negligentem ipso facto ferende. Quam donacionem, assignacionem ${ }^{g}$ fecimus ad ${ }^{h-}$ nostra acta $^{-i}$ reponi. Super quibus omnibus et singulis presentes ${ }^{j-n o s t r a s}$ litteras $^{-k}$ per notarium publicum causarumque et facti huiusmodi coram nobis scribam subscribi, nostri appen(sione) sigilli iussimus communiri. Acta sunt hec anno Domini millesimo quadringentesimo quadragesimo octavo, indicacione undecima, pontificatus sanctissimi in Christo patris et domini Nicolai pape quinti [anno scundo] die Solis vicesima tercia mensis Iuniil, hora vesperorum vel quasi, in curia nostra Radympnensi, presentibus honorabili et generosis: magistro Nicolao, Nicolao herede in Czelathycze, Nicolao et Johanne heredibus in Rudolowycze, Nicolao Skorczowsky ${ }^{m}$, Johanne de Morawsko $^{n}$ testibus ad premissa et circa.

Z. N. Et ego Sigismundus Michaelis de Wyschnya clericus Premisliensis diocesis, publicus imperiali auctoritate notarius.

${ }^{a}$ Wyd. 1: ultraneoque, $\quad{ }^{b}$ wyd. 1: contravenientibus, $\quad{ }^{c}$ wyd. 1: curiae, $\quad{ }^{d} w$ wyd. 1 brak, ${ }^{e}$ wyd. 1: prouenienti, ${ }^{f}$ wyd. 1: ibi in, ${ }^{g}$ wyd. 1: resignationem, ${ }^{h-i}$ wyd. 1: acta nostra, ${ }^{j-k}$ wyd. 1: litteras nostras, ${ }^{l}$ wyd. 1: Juliii, ${ }^{m}$ wyd. 1: Skorkowski, ${ }^{n}$ wyd. 1: Morawica. 
6.

Rudolowice, 2 X 1454

Bracia Jan wojski przemyski i Mikołaj miecznik przemyski kolatorzy kościoła parafialnego w Rudołowicach nadaja temu kościołowi łąke w Rudołowicach i druga w Bystrowicach.

Wyd.: S. Nakielski, Miechovia, s. 496-497.

Reg.: AAP 143, k. 202v-203; AAP 155, k. 114-114v (tu z data 1464 r.).

In nomine Domini amen. Ad perpetuam rei memoriam. Quoniam humanae naturae memoria breui interuallo temporis labitur, nisi scriptorum attestatione, sigillorumque appensione roboretur, proinde ego Ioannes tribunus et Nicolaus gladifer Praemislienses, fratres germani, haeredes vero veri et legitimi perpetuique villarum in Rudolowice et Bystrowice, collatores vero in Rudolowice, ordinis Sacrosancti Sepulchri Domini Hierosolymitani, non coacti, non compulsi, nec aliquo dolo seducti, sed mero animo deliberato, amicorumque nostrorum salubri freti consilio, pratum post nostram curiam ab antiquo fundatam, incipiendo a summitate, tam late et longe, sicut soli $\mathrm{ab}$ antiquo habuimus et tenuimus, usque ad fluuium seu gurgitem, qui currunt [!] eadem de villa, usque ad bona haereditaria domini Ptaczek, quod est iam insignitum per nobilem Andream nostrum protunc procuratorem et nostrorum fidelium videlicet Msciwoy et Stanislaum nostro de consensu et voluntate, cum loco piscinae nouae, quae potest effodi post antiquam piscinam et tabernam plebani antiquarum, tam late et longe sicut aqua potest diffundi. In Bystroiowice vero medium pratum lanei penes pratum plebani ab antiquo datum, quod pratum spectabat et pertinebat ad laneum $\mathrm{ab}$ antiquo desertum, quod nouissime tenuit quidam Vasko Ruthenus, situm parte ab una fluuii seu torrentis currentium ad molendinum eiusdem villae et alterius per planitiem alias nawssi, tacti nostra conscientia, ratione quorundam receptorum, quae ad ecclesiam praedictam videbantur pertinere, post faelicem obitum Alexii plebani immediati eiusdem ordinis non obstante privilegio fundationis, de quo nobis consistit et constat, damus, condescendimus, inscribimus et incorporamus, nostris cum legitimis successoribus dicta prata et locum piscinae, omnia et singula sic descripta honorabili dno Nicolao plebano de Rudolowice eiusdem ordinis protunc moderno et suis posteris dicti ordinis perpetuo et in aeuum, nihil pro nobis, nec pro nostris legitimis successoribus in eisdem reservantes, cum omnibus et singulis utilitatibus, quae in praemissis possunt fieri et esse. Ratione etiam cuiusdam additionis, assignationis, inscriptionis et resignationis, idem Nicolaus plebanus eiusdem ecclesiae et sui posteriores ordinis praescripti, nos et nostros legitimos successores pro huiusmodi receptis omnibus et singulis, quae fuerunt remittens, amplius inquietare non valebit, nec valebunt, seu omnino silere debebit et debebunt in perpetuum et in aeuum. In cuius rei testimonium sigilla nostra sunt appensa, praesentibus venerabilibus, honorabilibus et nobilibus domino Andrea de Strosza decano et officiali Praemisliensi, Iacobo vicecantore, Martino altarista, Sbilutho imperiali auctoritate notario et protunc consistorii, Burzymowski, Sigismundo et Wierzbiata Ptaczki nobilibus et aliis quam plurimis fide dignis. Datum in Rudolowice curiae nostrae [!!] feria quarta post festum sancti Michaelis principis angelorum anno Domini millesimo quadringentesimo quinquagesimo quarto. 


\section{BIBLIOGRAFIA}

Bodniak S., Drohojowski Stanisław, w: Polski słownik biograficzny, t. V (1939-1946).

Bukowski W., Miechów, w: Słownik historyczno-geograficzny województwa krakowskiego w średniowieczu, cz. IV, Kraków 2009.

Cynarski S., Kiryk F., Jan z Targowisk, w: Polski słownik biograficzny, t. X (1962-1964).

Fastnacht A., Słownik historyczno-geograficzny ziemi sanockiej w średniowieczu, cz. 3, Kraków 2002.

Klebowicz G., Organizacja parafialna diecezji przemyskiej obrządku łacińskiego w XIV-XVI wieku, Lublin 2013.

Kociubiński M., Księża diecezji przemyskiej do roku 1772, t. I, cz. 1-2, Jarosław-Przemyśl 1989 (maszynopis).

Kuś J., Jeszcze o manach jarosławskich. Szkic historyczno-archiwalny, w: Księga pamiątkowa [poświęcona doktorowi Zdzisławowi Koniecznemu z okazji 70. rocznicy urodzin], Przemyśl 2000.

Landau P., Ius patronatus. Studien zur Entwicklung des Patronats im Dekretalenrecht und der Kanonistik des 12. und 13. Jahrhunderts, Köln-Wien 1973.

Pawłowski F., Premislia sacra, Kraków 1869.

Pęckowski Z., Miechów. Studia z dziejów miasta i ziemi miechowskiej do roku 1914, Kraków 1967.

Pękalski P., O początku, rozkrzewieniu i upadku zakonu XX. Kanoników Stróżów św. Grobu Pańskiego, Kraków 1867.

Proksa M., Studia nad zamkami i dworami ziemi przemyskiej, Przemyśl 2001.

Skierska I., Obowiązek mszalny w średniowiecznej Polsce, Warszawa 2003.

Skrzyniarz R., Kanonicy Grobu Bożego i ich religijny, społeczny, edukacyjny i kulturowy wkład w rozwój mieszkańców ziem polskich w średniowieczu, Lublin 2015.

Skrzyniarz R., Źródła archiwalne w Polsce do dziejów zakonu Bożogrobców, w: Bożogrobcy w Polsce. Praca zbiorowa, Miechów-Warszawa 1999.

Słownik geograficzny Królestwa Polskiego i innych krajów słowiańskich, t. IV, Warszawa 1883.

Starnawska M., Między Jerozolimą a Łukowem. Zakony krzyżowe na ziemiach polskich w średniowieczu, Warszawa 1999.

Szady B., Prawo patronatu w Rzeczypospolitej w czasach nowożytnych. Podstawy i struktura, Lublin 2003.

Szymczakowa A., Szlachta sieradzka do końca XV wieku. Magnifici et generosi, Łódź 1998.

Śliwa T., Diecezja przemyska w połowie XVI wieku, Przemyśl 2015.

Tobiasz M., Bożogrobcy w Miechowie (w 800-lecie sprowadzenia zakonu do Polski), Nasza Przeszłość 17, 1963.

Trajdos T. M., Miechowici na ziemi przemyskiej za panowania Władysława II Jagiełły, Folia Historica Cracoviensia 4-5, 1997-1998.

Uruszczak W., Unio regnorum sub una corona non causat eorum unitatem. Unia Polski i Litwy w Krewie w 1385 r. Studium historyczno-prawne, Kraków 2017.

Urzędnicy centralni i nadworni Polski XIV-XVIII wieku. Spisy, Kórnik 1992.

Urzędnicy województwa ruskiego XIV-XVIII wieku. Spisy, opr. K. Przyboś, Wrocław 1987.

Wędzki A., Tuligłowy, w: Słownik starożytności słowiańskich, t. VI, Wrocław 1977.

Wolski M., Dzieje Pruchnika i okolic do końca XVI wieku, w: Pruchnik. Studia z dziejów miasta i okolic, Kraków 2014.

Zawitkowska W., W służbie pierwszych Jagiellonów. Życie i działalność kanclerza Jana Taszki Koniecpolskiego, Kraków 2005. 
On the beginnings of the church and parish in Tuligłowy

A contribution to the history of the Latin Church organisational structures in the diocese of Przemyśl

Summary

The state of knowledge about the beginnings and development of the organisation of the Catholic Church in the diocese of Przemyśl remains unsatisfactory, in spite of relatively rich literature. Of 163 parishes on that area, only less than twenty have relatively exhaustive monographs. A large majority of parish churches do not have foundational or erectional documents, while those existing are often false, so the whole picture of the development of the parochial network remains unclear. One example of such problems is the history of the church in Tuligłowy, supposed to be one of the oldest churches in the diocese. It is said to have been founded at the end of the $14^{\text {th }}$ century and conveyed to the Order of the Holy Sepulchre from Miechów in mid- $15^{\text {th }}$ century. The analysis of surviving source records shows a different picture. The church was founded in the second half of the $15^{\text {th }}$ century on the area belonging to the parish in Rudołowice and soon afterwards a separate parish was created near it. After about ten years the Order of the Holy Sepulchre took it over and subordinated it to the parish priests from Rudołowice, even though the parish in Tuligłowy retained its integrity. During the Reformation, in mid16th century, the church was turned into a Protestant chapel and only at the very end of the same century the owner of Tuligłowy rebuilt it and received the right of patronage over it. Then the Order of the Holy Sepulchre took it over once again. The history of the church in Tuligłowy is an example of the activities of that Order in the Przemyśl land, where they used falsified documents on a large scale in order to expand their possessions.

Translated of Rafat T. Prinke 